\title{
Heterogeneity of Cultured Leukemic Lymphoid Progenitor Cells from B Cell Precursor Acute Lymphoblastic Leukemia (ALL) Patients
}

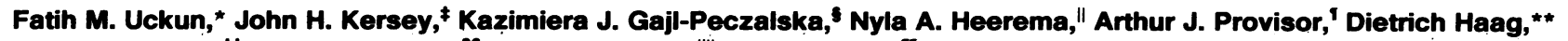

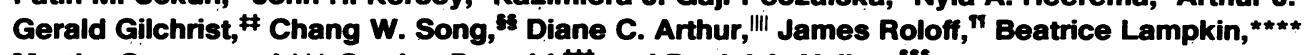 \\ Martha Greenwood, ${ }^{* *}$ Gordon Dewald, \# and Daniel A. Vallerasss

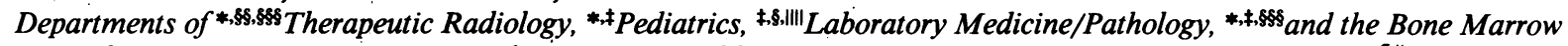 \\ Transplantation Program, University of Minnesota Health Sciences Center, Minneapolis, Minnesota 55455; ${ }^{1, \| D e p a r t m e n t s ~ o f ~ M e d i c a l ~}$ \\ Genetics and Pediatrics, Indiana University School of Medicine, Indianapolis, Indiana 46223; **Institute of Experimental/Comparative \\ Pathology and German Cancer Center, University of Heidelberg, 6900 Heidelberg, Federal Republic of Germany; ${ }^{\ddagger}, \neq \pm$ Mayo Clinic and \\ Mayo Foundation, Rochester, Minnesota 55901; "Children's Medical Center, Denver Children's Hospital, Colorado 80218; \\ ${ }^{* * * *}$ Cincinnati Hospital, Cincinnati, Ohio 45229; and ${ }^{* * *}$ University of Kentucky Medical Center, Lexington, Kentucky 40536
}

\begin{abstract}
Colony assays were performed for 50 patients with $B$ cell precursor acute lymphoblastic leukemia (ALL). Blast colony formation was observed for 33 patients, and the plating efficiency (PE) showed a marked interpatient variation, which indicates a pronounced biological heterogeneity at the level of leukemic progenitor cells. Notably, the mean PE of leukemic B cell precursors from patients with a pseudodiploid or near-diploid karyotype with structural chromosomal abnormalities (SCA) was significantly higher than the mean PE of normal diploid or hyperdiploid cases. All patients who had SCA involving 7p13, 11q23-24, or 12p11-13, and patients with a Philadelphia chromosome had high $P E$ values. The $S$ phase percentage, expression of CD19 antigen, and relapse status were also correlated with PE. Significantly, colony blasts had slightly different surface marker profiles in each case and were common ALL antigen negative in $33 \%$ of cases, which indicates the existence of a marked immunological heterogeneity at the level of leukemic progenitor cells.
\end{abstract}

\section{Introduction}

Leukemic progenitor cells have been implicated in maintenance-expansion of leukemic cell populations, and, therefore, analysis of the biological diversity of this clonogenic self-renewing subpopulation is of paramount importance. The current paucity of knowledge regarding acute lymphoblastic leukemia $(\mathrm{ALL})^{1}$ progenitor cells largely reflects the historic diffi-

Presented in part at the 28th Annual Meeting of the American Society of Hematology, San Francisco, December, 1986, and as abstracts (1986. Blood. 68:155) (1986. Blood. 68:268). This is publication No. 30 from the Center for Experimental Transplantation and Cancer Research.

Address all correspondence to Dr. Uckun, University of Minnesota, Box 356, Mayo Memorial Bldg., 420 Delaware St. S. E., Minneapolis, MN 55455.

Received for publication 29 September 1986 and in revised form 22 April 1987.

1. Abbreviations used in this paper: ALL, acute lymphoblastic leukemia; $\mathrm{C} \mu$, cytoplasmic $\mu$; CALLA, common ALL antigen; DI, DNA index; FAB, French-American-British; FITC, fluorescein isothiocya-

J. Clin. Invest.

(C) The American Society for Clinical Investigation, Inc.

0021-9738/87/09/0639/08 \$2.00

Volume 80, September 1987, 639-646 culties in cloning fresh ALL blasts in vitro (1-8). In recent years, considerable effort has been invested in developing novel cell culture techniques to reveal information about the biological characteristics of leukemic progenitor cells in ALL (1-8). These techniques may provide greater understanding of the basic biology of ALL and insight into pathogenesis.

Recently, we have developed a colony assay system that enables us to culture leukemic progenitor cells in B cell precursor ALL (6). The purposes of the present analysis were $(a)$ to elucidate the proliferative and immunophenotypic characteristics of 50 patients with B cell precursor ALL at the level of leukemic progenitor cells, and $(b)$ to determine whether the in vitro growth characteristics of ALL blasts correlate with more commonly measured disease- and host-related parameters. To our knowledge, this report is the first detailed comparative analysis of the in vitro proliferative activity of leukemic B lineage lymphoid progenitor cells. We provide evidence for $(a)$ a significant relationship between high plating efficiency (PE) of leukemic B lineage lymphoid progenitor cells, structural chromosomal abnormalities (SCA), and high S phase percentage, and $(b)$ a marked biological and immunological heterogeneity at the level of leukemic progenitor cells in B cell precursor ALL.

\section{Methods}

Patient material. 50 patients with B cell precursor ALL were included in this study. Bone marrow aspirate samples were procured by routine procedures. Morphological classification was performed on WrightGiemsa stained slides according to a modification of the original French-American-British (FAB) nomenclature (9). Diagnosis was based upon the morphological, cytochemical, and surface marker profiles of marrow blasts.

Surface marker analyses. Marrow blasts were isolated by a single centrifugation of aspirate samples on Ficoll-Hypaque $\left(1.077 \mathrm{~g} / \mathrm{cm}^{3}\right)$. Immunological marker analyses by indirect immunofluorescence and flow cytometry were performed, as previously described (6), using monoclonal B cell panel antibodies BA-1 (anti-CD24), BA-2 (antiCD9), BA-3 (anti-CD10), and B43 (anti-CD19), which define B lineage-associated surface determinants, as well as $\mathrm{T}$ cell panel antibodies 35.1 (anti-CD2), T1O1 (anti-CD5), and 3A1 (anti-CD7), which define $T$ lineage-differentiation antigens. Fluorescein isothiocyanate (FITC)labeled goat $\mathrm{F}\left(\mathrm{ab}^{\prime}\right)_{2}$ anti-mouse IgG (Cappel Laboratories, Cochran-

nate; mAb, monoclonal antibody(ies); MEM, minimal essential medium; PE, plating efficiency; \%S, percentage of cells in S phase; SCA, structural chromosomal abnormalities; slg, surface immunoglobulin; TdT, terminal deoxynucleotidyl transferase; UPN, unique patient number(s); WBC, white cell count. 
ville, NC) served as secondary antibody. Cell surface immunoglobulin (sIg) was assayed by direct immunofluorescence with FITC-conjugated goat anti-human total Ig (Kallestad Laboratories, Inc., Austin, TX). An IgG2a murine myeloma protein (UPC 10; Litton Bionetics, Inc., Kensington, MD) substituted for monoclonal antibodies ( $\mathrm{mAb}$ ) was used for background fluorescence. Cells were analyzed for immunofluorescence using a cytofluorograph (Spectrum III; Ortho Diagnostic Systems, Inc., Raritan, NJ).

Karyotypic analyses. Banded chromosome analyses were performed on direct, overnight, and in some cases, synchronized preparations of fresh bone marrow samples. Several methods of banding were used including $G$ banding with Wright's stain, GTG (G bands using trypsin and Giemsa) banding, and QFQ ( $Q$ bands using fluorescence by quinacrine mustard) banding. Chromosome abnormalities were designated using the 1985 International System for Human Cytogenetics Nomenclature (10). An abnormal clone was defined as $\geq 2$ metaphase cells with identical structural abnormalities or identical extra chromosomes, or $\geq 3$ metaphases with identical missing chromosomes. For the case to be considered cytogenetically normal, i.e., normal diploid, at least 15 metaphase cells had to be examined and all were found to be normal. The details of the methodology have been published (11-13).

Flow microfluorometric DNA analysis. DNA content and cell cycle distribution of leukemic marrow blasts were evaluated by flow cytometric DNA analysis as previously described (14-17). In brief, density gradient-separated fresh marrow blasts were washed twice in phosphate-buffered saline, fixed with $96 \%$ ethanol, resuspended in $0.5 \mathrm{ml}$ of a $0.5 \%$ pepsin solution $(3,000 \mathrm{U} / \mathrm{mg}$, Serva, Heidelberg, FRG) in $0.9 \%$ $\mathrm{NaCl}$ containing $0.25 \% \mathrm{HCl}$, incubated $5 \mathrm{~min}$ at room temperature on a laboratory shaker, and flushed 100 times through a thin-tipped Pasteur pipette for dispersal. The cell suspensions were adjusted to $1 \times 10^{5}$ cells $/ \mathrm{ml}$ in a freshly prepared DNA-specific fluorochrome solution that consisted of $0.5 \mu \mathrm{g} / \mathrm{ml} \mathrm{4',6-diamidino-2-phenylindol} \mathrm{and} 20 \mu \mathrm{g} / \mathrm{ml} \mathrm{ri-}$ bonuclease (from bovine pancreas, $100 \mathrm{Kunitz} \mathrm{U} / \mathrm{mg}$, Serva) in $0.1 \mathrm{M}$ tris buffer at pH 7.6. After staining for $30 \mathrm{~min}$, the nuclear fluorescence was measured with a pulse cytophotometer (ICP 22; Phywe A. G., Gottingen, FRG) using the $365 \mathrm{~nm}$ ultraviolet light of a mercury high pressure lamp for excitation and a $590 \mathrm{~nm}$ barrier filter for measurement of the emitted red light pulses as described (15). After reaching 10,000 counts in the peak channel, measurements were stopped, and the data, which were stored in a multichannel and analyzer (MCA 8100; Canberra Industries, Meriden, CT), were transferred to the magnetic tape of a graphic computer system (GS 4051 combined with a digital plotter 4662; Tektronix, Inc., Beaverton, OR) for further evaluation. The data for the original pulse-height distributions were processed by means of a computer program that has been described in detail (14). Standards of identically stained, ethanol-fixed human normal bone marrow mononuclear cells $(n=5)$ as well as normal peripheral blood mononuclear cells $(n=6)$ were used for calibration of the 2c-peak channel number. We also used a mixture of stained normal bone marrow mononuclear cells and leukemic marrow cells as a reference standard to identify the modal fluorescence of $G_{0} / G_{1}$ phase leukemic blasts relative to that of $G_{0} / G_{1}$ phase normal cells. A leukemia stem line with a DNA index (DI) (the ratio of the channel numbers of the leukemic and normal $G_{0} / G_{1}$ cells) of 1.00 was determined to be present if the percentage of diploid $G_{0} / G_{1}$ cells was $>20 \%$ more than the percentage of "nonblast" cells in Wright-Giemsa stained differential counts. The coefficient of variation $(C V)$ of the $G_{0} / G_{1}$ phase modal channel numbers (i.e., fluorescence distribution of $G_{0} / G_{1}$ cells) was determined using the formula $C V=(H M \times 100) /(N \times 2.35)$, where $H M$ was the width of the $\mathrm{G}_{0} / \mathrm{G}_{1}$ peak at half-maximum height and $N$ was the modal channel number of the $G_{0} / G_{1}$ peak.

Colony assay and analysis of colony blasts. B cell precursor ALL blasts from all 50 patients were assayed for in vitro colony formation using a novel model system that has recently been described (6). Density gradient-separated fresh bone marrow blasts were suspended in alpha minimal essential medium (MEM) supplemented with $0.9 \%$ methylcellulose, $15 \%$ fetal calf serum, $15 \%$ platelet-rich human plasma, $10 \%$ phytohemagglutinin-leucocyte-conditioned medium, $1 \%$ MEM vitamin solution, $0.5 \%$ MEM amino acids solution, $0.5 \% \mathrm{MEM}$ nonessential amino acids solution, $2 \mathrm{mM}$ L-glutamine, $1 \mathrm{mM}$ sodium pyruvate, $50 \mu \mathrm{M}$ 2-mercaptoethanol, $4 \mu \mathrm{g} / \mathrm{ml} \mathrm{D-L-serine,} \mathrm{and} 4 \mu \mathrm{g} / \mathrm{ml}$ asparagine. Duplicate $1 \mathrm{ml}$ samples containing 100,000 blasts were cultured in $35-\mathrm{mm}$ Petri dishes for $7 \mathrm{~d}$ at $37^{\circ} \mathrm{C}$ in a humidified $5 \% \mathrm{CO}_{2}$ atmosphere as described (6). On day 7 , colonies containing $>20$ cells were counted using an inverted phase microscope with high optical resolution. Subsequently, all colonies were harvested for further morphological, cytochemical, and immunological analyses of colony blasts. Day 7 colony blasts showed $90-95 \%$ viability as determined by a standard trypan blue dye exclusion test. Their morphology was studied in Wright-Giemsa stained cytospin preparations. In cytochemical studies, colony cells were evaluated for staining by periodic acid-Schiff and Sudan Black B, for nonspecific esterase and myeloperoxidase activity as reported (6). Cultured blasts differed morphologically from the bulk of the preculture patients' marrow blasts in that the former had a bigger size, more prominent vacuolation, more prominent nucleoli, and a more irregular nuclear membrane. Colony blasts were periodic acid-Schiff-positive, but Sudan Black-, myeloperoxidase-, and nonspecific esterase-negative. In 10 cases with sufficient day 7 colony blasts (unique patient numbers [UPN] 3, 7, 13, 19, 22-24, 32, 34, and 39), 10,000 cells from pooled day 7 colonies were replated to measure the self-renewal ability of blast progenitors. The surface marker profiles were analyzed on cytospin slides, as previously described (6), using a broad panel of murine $\mathrm{mAb}$ that defines lymphoid and myeloid-erythroid differentiation antigens. Specifically, we used the mAb 35.1 (anti-CD2), BA-2 (anti-CD9), BA-3 (anti-CD10), B43 (anti-CD19), Leu 14 (anti-CD22) (Becton Dickinson \& Co., Orangeburg, NY), BA-1 (anti-CD24), anti-MY7 (anti-CD13), anti-MY8 (pan-myeloid), and R10 (anti-glycophorin A). FITC-conjugated goat $F\left(a^{\prime}\right)_{2}$ anti-mouse IgG (Cappel Laboratories) was used as a second antibody. For background fluorescence, an IgG2a murine myeloma protein (UPC 10; Litton Bionetics, Inc.) was substituted for mAb. Furthermore, terminal deoxynucleotidyl transferase (TdT) activity of colony blasts was determined in the last 14 patients by indirect immunofluorescence on methanol-fixed cytospin preparations using immunadsorbent-purified anti-rabbit TdT serum $(20 \mu \mathrm{g} / \mathrm{ml})$ and FITC-conjugated goat $\mathrm{F}\left(\mathrm{ab}^{\prime}\right)_{2}$ anti-rabbit IgG $(60 \mu \mathrm{g} / \mathrm{ml})$. Cell slg was tested by direct fluorescence with FITC-conjugated goat anti-human total Ig (Kallestad Laboratories, Inc.). Cells were evaluated for cytoplasmic $\mu(\mathrm{C} \mu)$ chains using FITC-conjugated $\mathrm{F}\left(\mathrm{ab}^{\prime}\right)_{2}$ goat anti-human IgM heavy chain-specific anti- $\mu$ (Tago Inc., Burlingame, CA). The percentage of cells expressing each marker was determined using a fluorescent microscope (Carl Zeiss, Inc., Thornwood, NY) equipped with Ploem epi illumination. Quantitative data were obtained from examination of 100-200 cells. Banded chromosome analyses were performed on colony blasts using a modification of our standard procedure (13). In brief, $1 \times 10^{6}$ blasts from pooled colonies were cultured in flat-bottom tissue-culture plates for $17 \mathrm{~h}$ at $37^{\circ} \mathrm{C}$ in a humidified $5 \% \mathrm{CO}_{2}$ atmosphere in the presence of $10^{-7} \mathrm{M}$ amethopterin. Subsequently, thymidine $\left(10^{-5} \mathrm{M}\right)$ and adenosine $(10 \mu \mathrm{g} / \mathrm{ml})$ were added and cells were incubated for $4 \mathrm{~h}$. Cells were then subjected to colcemid, transferred to siliconized centrifuge tubes, centrifuged, and resuspended in a prewarmed, hypotonic $\mathrm{KCl}$ solution (11.5 g KCl, $0.1 \mathrm{~g}$ EDTA, $2.4 \mathrm{~g}$ Hepes in $500 \mathrm{ml} \mathrm{H}_{2} \mathrm{O}$, pH 7.4, 37 ${ }^{\circ} \mathrm{C}$ ). After a 55 -min incubation at $37^{\circ} \mathrm{C}$, cells were fixed using a 3:1 methanol/acetic acid solution, and slides were prepared by conventional techniques. $\mathrm{G}$ banding was performed with Wright's stain. 20 to 50 metaphases were completely analyzed, and 5 to 10 cells were karyotyped.

Statistical analysis. We used standard statistical methods, including two-sample $t$ tests, chi-square, one-way analysis of variance, and multiple regression analysis to evaluate the data.

\section{Results}

Clinical and diagnostic features. 50 patients with B cell precursor ALL were studied. Patient data are summarized in 
Table I. The patients ranged in age from 1 to $41 \mathrm{yr}$ (median, 5 yr). Most patients $(90 \%)$ were children or adolescents $<16 \mathrm{yr}$ of age. There were 24 males and 26 females. 10 patients were in relapse and 40 , newly diagnosed. The white cell count (WBC) at the time of diagnosis varied from $900 / \mu 1$ to $328,000 / \mu \mathrm{l}$ (median, 30,950/ $\mu \mathrm{l}) .21$ patients $(42 \%)$ had a WBC of $\geq 50,000 / \mu \mathrm{l}$. 44 patients were morphologically classified as L1-ALL, whereas the subtype of the remaining 6 was L2. Bone marrow aspiration samples that were evaluated in the present study contained $63-100 \%$ (median, $91 \%$ ) blasts.

Cytogenetic and cytokinetic features and in vitro clonogenicity of leukemic $B$ cell precursor marrow blasts. Karyotypic analyses were performed in 35 patients (Table II). In all 35 cases, cytogenetic studies were adequate to determine the modal chromosome number. Banding was successful in 32 cases $(91 \%)$. There were 12 patients with a normal diploid karyotype (UPN 2, 8, 12, 25, 29, 30, 34, 35, 38, 41, 48, and 49), 8 patients with a pseudodiploid karyotype (UPN 3, 4, 7, $17,28,39,43$, and 47), 3 patients with a hypodiploid karyotype (UPN 22, 23, and 44), and 11 patients with a hyperdiploid karyotype of whom 4 had 47 chromosomes (UPN 9, 14, 36, and 45) and 7 had $>50$ chromosomes (UPN 5, 20, 26, 33, 40, 42, and 46). 16 of the 32 cases with successful banding had SCA. Among these 16 cases, SCA involved $7 \mathrm{p} 13$ in 2 cases (UPN 3 and 39), 11q23-24 in 2 cases (UPN 3 and 17), 12p1113 in 4 cases (UPN 4, 22, 39, and 43), and 22q11 (Philadelphia chromosome positive) in 2 cases (UPN 42 and 47).

Using flow microfluorometric DNA analysis, we determined the cellular DNA content distributions of 4',6-diamidino-2-phenylindol-stained leukemic blasts in freshly obtained marrow samples from 31 of 50 patients (Table II). Of these 31 cases, $21(68 \%)$ had cytophotometrically diploid or near-diploid primary leukemic stem lines (DI of 0.96-1.04). Hyperdiploid DNA content (DI > 1.04) was evident in nine patients $(29 \%)$ with a median abnormal DI of 1.1 . Three of these nine cases (UPN 19, 21, and 23) had hyperdiploid primary lines with diploid secondary lines (Table II). The S phase fraction of blasts in leukemic marrow samples varied widely between patients with a median value of $4.8 \%$ (Table II). By

Table I. Patient Characteristics

\begin{tabular}{lll}
\hline Sex & Male & $n=24$ \\
Age $(y r)$ & Female & $n=26$ \\
& $<16$ & $n=45$ \\
& $\geq 16$ & $n=5$ \\
& Median & 5 \\
Status & Range & $1-41$ \\
& New & $n=40$ \\
FAB & Relapse & $n=10$ \\
WBC at diagnosis per & L1 & $n=44$ \\
microliter & L2 & $n=6$ \\
& $<50,000$ & $n=29$ \\
& $\geq 50,000$ & $n=21$ \\
Blasts in bone marrow $(\%)$ & Median & 30,950 \\
& Range & $900-328,000$ \\
& $<90$ & $n=14$ \\
& $\geq 90$ & $n=36$ \\
& Median & 91 \\
& Range & $63-100$ \\
& &
\end{tabular}

comparison, the median value for the $\mathrm{S}$ phase fraction of mononuclear cells from five normal bone marrow aspirate samples was $6.7 \%$.

Fresh bone marrow samples from all $50 \mathrm{~B}$ cell precursor ALL patients were assayed for B lineage blast colony formation (Table II). 33 of these samples (66\%) grew spherical-elliptical clusters of 10 to 20 tightly associated cells within $3 \mathrm{~d}$. In these cases, blast colonies containing $>20$ cells were enumerated on day 7 , pooled, and analyzed. The cultures from the remaining 17 patients (34\%) showed no growth. The PE of blast progenitor cells in successful cultures varied from $0.090 \%$ (i.e., 90 colonies $/ 10^{5}$ marrow blasts) to $2.631 \%$ (i.e., 2631 colonies $/ 10^{5}$ marrow blasts) (median, $0.408 \%$; i.e., 408 colonies/ $10^{5}$ marrow blasts). The self-renewing ability of day 7 colony blasts was evaluated in replating experiments in 10 patients, and secondary blast colonies were obtained in 9 of these cases. Secondary colonies were loose, contained 50 to 200 cells, and started to disperse on day 5 or 6 . The secondary PE of B cell precursor ALL progenitors varied from $2.50 \%$ (i.e., $250 \mathrm{sec}$ ondary colonies $/ 10^{4}$ colony blasts) to $9.03 \%$ (i.e., 903 secondary colonies $/ 10^{4}$ colony blasts) (median, $7.23 \%$ i.e., $723 \mathrm{sec}$ ondary colonies $/ 10^{4}$ colony blasts) (data not shown).

Immunophenotypic features of fresh marrow blasts and morphological, cytochemical, immunophenotypic, and cytogenetic features of primary day $7 \mathrm{~B}$ lineage colony blasts. 46 of the 50 patients $(92 \%)$ expressed the B lineage-associated surface marker CD9. The fraction of $\mathrm{CD}^{+}$marrow cells in these patients ranged from 24 to $98 \%$ (median, $79 \%$ ). 49 patients (98\%) expressed detectable amounts of common ALL antigen (CALLA) (CD10) by flow cytometric analysis of BA-3 mAb binding, and $22-98 \%$ (median, 87\%) of cells were CALLA ${ }^{+}$. The marrow blasts from all 50 patients expressed the CD24 surface antigen, and $42-98 \%$ (median, $87.5 \%$ ) of cells were $\mathrm{CD}_{24}{ }^{+}$. All of 21 patients (100\%) tested expressed the CD19/ B43 antigen, and 58-96\% (median, 87\%) of cells were CD19/ $\mathrm{B} 43^{+}$. These immunological marker profiles are consistent with $B$ lineage affiliation. In a few cases, a small number of $\mathrm{CD}^{+}$and/or $\mathrm{sIg}^{+}$cells were present among the bone marrow mononuclear cells (probably contaminating normal $T$ and $B$ lymphocytes, respectively). By comparison, the mean percentages of positive mononuclear cells in normal marrow samples $(n=3)$ were $41 \%$ for CD2, 6\% for CD9, 3\% for CD10, $5 \%$ for CD19, $9 \%$ for CD24, and $11 \%$ for sIg. The expression of CD9, CD10, CD19, and CD24 on colony blasts from B cell precursor ALL patients correlated with the expression of the same determinants on the initial fresh marrow blasts. As shown in Table III, colony blasts were $\mathrm{TdT}^{+}(14 / 14), \mathrm{CD}^{+}(27 / 28)$, $\mathrm{CD}_{19}{ }^{+}(32 / 33), \mathrm{CD}^{+} 4^{+}(32 / 33), \mathrm{CD} 22^{+}(6 / 10)$, but lacked sIg $(12 / 12)$ or $\mathrm{C} \mu$ heavy chains (11/12). Also, they did not express the T lineage surface marker CD2 $(21 / 21)$, the myelomonocytic surface markers MY7 (14/14) and MY8 (20/20), nor the erythroid marker glycophorin A (9/9). These immunological surface marker profiles are consistent with B cell precursor ALL. In one patient whose fresh marrow blasts were $\mathrm{CD}{ }^{+} \mathrm{C}^{+}{ }^{+} \mathrm{sIg}^{-}$, colony blasts were also $\mathrm{CD} 19^{+} \mathrm{C}^{+} \mathrm{sIg}^{-}$and therefore consistent with pre-B ALL. Initial karyotypic analyses of colony blasts were performed in three cases (UPN 39, 42, and 47) with documented chromosomal abnormalities before culture. The malignant clone in the fresh marrow sample of UPN 39 had a 6;12 translocation and a deletion of the short arm of chromosome 7. By comparison, two clones were identified among colony blasts. One was identical to the clone 
Table II. Cytogenetic and Cytokinetic Features and In Vitro Clonogenicity of Leukemic B Cell Precursor Marrow Blasts

\begin{tabular}{|c|c|c|c|c|c|}
\hline UPN & Karyotype* & DI & $\% \mathrm{~S}$ & Colonies/ $10^{5}$ BMMNC & $\%$ PE \\
\hline 1 & $46, X Y$ & 1.00 & 14.7 & $205(175,235)$ & 0.205 \\
\hline 2 & $46, X Y$ & 1.04 & 4.2 & $0(0,0)$ & 0.001 \\
\hline 3 & $46, \mathrm{XY} / 46, \mathrm{XY}, \mathrm{t}(7 ; 11)(\mathrm{p} 13 ; \mathrm{q} 24)$ & 1.04 & 14.5 & $2,631(2,458,2,804)$ & 2.631 \\
\hline 4 & $46, \mathrm{XX}, \operatorname{del}(12)(\mathrm{p} 11), \mathrm{t}(2 ; 7)(? \mathrm{q} 11 ; ? \mathrm{q} 11)$ & 1.00 & 2.9 & $514(509,520)$ & 0.514 \\
\hline 5 & $46, \mathrm{XY} / 54, \mathrm{XY},+\mathrm{X},+5,+6,+8,+18,+21,+22, \mathrm{dup}(1)(\mathrm{q} 21-\mathrm{q} 32),+\operatorname{mar}$ & 1.17 & 14.4 & $768(750,785)$ & 0.768 \\
\hline 6 & ND & 1.04 & 3.6 & $0(0,0)$ & 0.001 \\
\hline 7 & $46, X Y / 46, X Y, 19 q+$ & 1.00 & 6.0 & $1,850(1,669,2,030)$ & 1.850 \\
\hline 8 & $46, \mathrm{XX}$ & 1.00 & 10.7 & $197(183,210)$ & 0.197 \\
\hline 9 & $46, X Y / 47, X Y,+21$ & 1.04 & 3.0 & $160(160,160)$ & 0.160 \\
\hline 10 & ND & 1.00 & 0.6 & $0(0,0)$ & 0.001 \\
\hline 11 & ND & 0.96 & 1.5 & $113(100,125)$ & 0.113 \\
\hline 12 & $46, X Y$ & 1.00 & 4.6 & $90(80,100)$ & 0.090 \\
\hline 13 & ND & 1.08 & 17.3 & $1,150(1,100,1,200)$ & 1.150 \\
\hline 14 & $46, \mathrm{XX} / 46, \mathrm{XX}, \mathrm{t}(5 ; 15)(\mathrm{p} 15 ; \mathrm{q} 11) / 47, \mathrm{XX},+22, \mathrm{t}(5 ; 15)(\mathrm{p} 15 ; \mathrm{q} 11)$ & 1.00 & 1.5 & $210(203,216)$ & 0.210 \\
\hline 15 & ND & 1.04 & 2.0 & $0(0,0)$ & 0.001 \\
\hline 16 & ND & 1.00 & 4.4 & $505(500,510)$ & 0.505 \\
\hline 17 & $46, X Y / 46, X Y, \operatorname{del}(11)(q 23)$ & 1.04 & 6.4 & $495(490,500)$ & 0.495 \\
\hline 18 & ND & 1.08 & 5.9 & $257(233,280)$ & 0.257 \\
\hline 19 & ND & $1.00,1.15$ & 9.4 & $679(654,703)$ & 0.679 \\
\hline 20 & $54, \mathrm{XY} / 55, \mathrm{XY} / 57, \mathrm{XY} \mathrm{Y}^{\ddagger}$ & 1.20 & 3.3 & $0(0,0)$ & 0.001 \\
\hline 21 & ND & $1.00,1.10$ & 22.1 & $185(166,203)$ & 0.185 \\
\hline 22 & $\begin{array}{l}45, \mathrm{XX},-17,-22, \operatorname{del}(6)(\mathrm{q} 13 \mathrm{q} 21), \operatorname{del}(13)(\mathrm{q} 22), \mathrm{t}(3 ; 12)(\mathrm{q} 2 \mathrm{i} ; \mathrm{p} 13),+\operatorname{der}(22) \\
\mathrm{t}(17 ; 22)(\mathrm{q} 11 ; \mathrm{p} 12)\end{array}$ & 1.00 & 2.8 & $1,235(1,100,1,369)$ & 1.235 \\
\hline 23 & $46, \mathrm{XX} / 45, \mathrm{XX},-7,2 \mathrm{p}-$ & $1.00,1.20$ & 9.9 & $2,150(2,000,2,300)$ & 2.150 \\
\hline 24 & ND & 1.10 & 6.8 & $490(479,500)$ & 0.490 \\
\hline 25 & $46, \mathrm{XX}$ & 1.00 & 4.4 & $0(0,0)$ & 0.001 \\
\hline 26 & $52, \mathrm{XX}$ & 1.08 & 6.7 & $0(0,0)$ & 0.001 \\
\hline 27 & ND & ND & ND & $0(0,0)$ & 0.001 \\
\hline 28 & $46, X X / 46, X X, \operatorname{del}(6)(q 22)$ & 1.00 & 5.8 & $114(103,125)$ & 0.114 \\
\hline 29 & $46, X Y$ & $0.66,1.00$ & 2.4 & $0(0,0)$ & 0.001 \\
\hline 30 & $46, X Y$ & 1.00 & 4.8 & $204(189,219)$ & 0.204 \\
\hline 31 & ND & 1.00 & 2.0 & $0(0,0)$ & 0.001 \\
\hline 32 & ND & ND & ND & $408(373,443)$ & 0.408 \\
\hline 33 & $\begin{array}{l}46, \mathrm{XX} / 53, \mathrm{XX},+5,+6,-7,-8,+11,+14,+15,+21,+3 \mathrm{mar} / 54, \mathrm{XX},+4,+6 \\
\quad-8,+11,+15,+17,+18,+21,+2 \mathrm{mar} / 54, \mathrm{XX},+4,+6,-8,+10,+11,+14 \\
\quad+18,+3 \mathrm{mar}\end{array}$ & ND & ND & $0(0,0)$ & 0.001 \\
\hline 34 & $46, X Y$ & ND & ND & $255(228,282)$ & 0.255 \\
\hline 35 & $46, X Y$ & ND & ND & $125(98,152)$ & 0.125 \\
\hline 36 & $46, X Y / 47, X Y,+21$ & 1.00 & 11.9 & $0(0,0)$ & 0.001 \\
\hline 37 & ND & ND & ND & $0(0,0)$ & 0.001 \\
\hline 38 & $46, X X$ & ND & ND & $255(240,270)$ & 0.255 \\
\hline 39 & $46, X X, t(6 ; 12)(p 21 ; p 13), \operatorname{del}(7)(p ? 13 p ? 22)$ & ND & ND & $645(614,676)$ & 0.645 \\
\hline 40 & $46, X Y / 51, X Y,+X,+4,+17,+18,+21$ & ND & ND & $0(0,0)$ & 0.001 \\
\hline 41 & $46, X Y$ & ND & ND & $0(0,0)$ & 0.001 \\
\hline 42 & $54, \mathrm{XY},+\mathrm{Y},+4,+6,+10,+14,+18,+21, \mathrm{t}(9 ; 22)(\mathrm{q} 34 ; \mathrm{q} 11),+\operatorname{der}(22), \mathrm{t}(9 ; 22)(\mathrm{q} 34 ; \mathrm{q} 11)$ & ND & ND & $1,154(1,025,1,282)$ & 1.154 \\
\hline 43 & $46, X X / 46, X X, t(12 ; 18)(\mathrm{p} 12 ; q 12)$ & ND & ND & $2,042(1,785,2,300)$ & 2.042 \\
\hline 44 & $46, \mathrm{XX} / 45, \mathrm{XX},-7,-9,-9,-18,-21,+\operatorname{der}(21), \mathrm{t}(? 7 ; 21)(? \mathrm{q} 22 ; \mathrm{q} 22),+3 \mathrm{mar}$ & ND & ND & $266(258,274)$ & 0.266 \\
\hline 45 & $47, \mathrm{XX}, \mathrm{t}(2 ; 16)(\mathrm{p} 11 ; \mathrm{p} 11),+\mathrm{mar}$ & ND & ND & $1,154(1,050,1,258)$ & 1.154 \\
\hline 46 & $46, \mathrm{XY} / 56, \mathrm{XY},+\mathrm{X},+4,+5,+11,+14,+15,+18,+19,+21,+22$ & ND & ND & $350(325,374)$ & 0.350 \\
\hline 47 & $46, X Y,-15, t(9 ; 22)(q 34 ; q 11),+\operatorname{mar}$ & ND & ND & $1,388(1,401,1,375)$ & 1.388 \\
\hline 48 & $46, X Y$ & ND & ND & $0(0,0)$ & 0.001 \\
\hline 49 & $46, X X$ & ND & ND & $0(0,0)$ & 0.001 \\
\hline 50 & ND & ND & ND & $311(294,327)$ & 0.311 \\
\hline
\end{tabular}

\footnotetext{
* Banded chromosome analyses were performed as described (15-17). Banding was unsuccessful only in UPN 1,20 , and $26 . \quad{ }^{\ddagger}$ Although all three metaphases were hyperdiploid, each had a different karyotype. DI and $\% \mathrm{~S}$ were determined by DNA-flow cytometry as described (10, 11). Leukemic $B$ cell precursors were cultured in vitro for $7 \mathrm{~d}$ and assayed for colony formation as previously described (6). Data are shown as average number of blast colonies (number of blast colonies in individual replicate dishes) and \% PE.
} 
Table III. Immunophenotypic Features of Fresh Marrow Blasts and Day 7 B Lineage Colony Blasts from B Cell Precursor ALL Patients*

\begin{tabular}{|c|c|c|c|c|c|c|}
\hline \multirow[b]{3}{*}{ Antigen } & \multicolumn{3}{|c|}{ Fresh bone marrow samples } & \multicolumn{3}{|c|}{ Primary day 7 blast colonies } \\
\hline & \multirow{2}{*}{$\begin{array}{l}\text { Percent } \\
\text { positive cases }\end{array}$} & \multicolumn{2}{|c|}{ Percent positive cells } & \multirow{2}{*}{$\begin{array}{l}\text { Percent } \\
\text { positive cases }\end{array}$} & \multicolumn{2}{|c|}{ Percent positive cells } \\
\hline & & Median & Range & & Median & Range \\
\hline $\mathrm{CD} 2,35.1$ & $18(9 / 50)$ & 13 & $10-24$ & $0(0 / 21)$ & - & - \\
\hline CD9, BA-2 & $92(46 / 50)$ & 79 & $24-98$ & $96(27 / 28)$ & 85 & 49-99 \\
\hline CD10, BA-3 & $98(49 / 50)$ & 87 & $22-98$ & $67(22 / 23)$ & 75 & $22-100$ \\
\hline CD19, B43 & $100(21 / 21)$ & 87 & $58-96$ & $97(32 / 33)$ & 74 & 13-99 \\
\hline CD22, Leu14 & - & 一 & - & $60(6 / 10)$ & 45 & $15-75$ \\
\hline CD24, BA-1 & $100(50 / 50)$ & 88 & $42-98$ & $97(32 / 33)$ & 75 & $10-100$ \\
\hline slg & $16(8 / 50)$ & 14 & $11-31$ & $0(0 / 12)$ & - & - \\
\hline $\mathrm{C} \mu$ & - & - & - & $8(1 / 12)$ & - & - \\
\hline TdT & - & - & - & $100(14 / 14)$ & 100 & $85-100$ \\
\hline CD13, MY7 & - & - & - & $0(0 / 14)$ & - & - \\
\hline MY8 & - & - & - & $0(0 / 20)$ & - & - \\
\hline Glycophorin A, R10 & - & - & - & $0(0 / 9)$ & - & - \\
\hline
\end{tabular}

* The immunophenotypes of leukemic B cell precursors were determined by immunofluorescence staining techniques and flow cytometry (fresh marrow blasts) of immunofluorescence microscopy (colony blasts), as described in Methods. Cases were considered positive when $>10 \%$ of cells reacted with the antibody used. Data are presented as percent positive cases, as well as percent positive cells in cases that were positive cells in cases that were positive for the markers analyzed.

detected in fresh marrow $(46, \mathrm{XX}, \mathrm{t}[6 ; 12]$ [p21; p13], del[7] [p13p22]), whereas the second clone had the same 6;12 translocation but did not show the deletion of chromosome 7 (46, $\mathrm{XX}, \mathrm{t}[6 ; 12]$ [p21; p13]). In UPN 42, colony blasts had clonal cytogenetic abnormalities identical to the karyotype of fresh marrow blasts $(54, \mathrm{XY},+\mathrm{Y},+4,+6,+10,+14,+18,+21$, $\mathrm{t}[9 ; 22]$ [q34; q11], $+\operatorname{der}[22], \mathrm{t}[9 ; 22]$ [q34; q11]). Interestingly, in UPN 47, the cytogenetic features of colony blasts differed from those of karyotyped fresh marrow blasts. Specifically, the malignant clone detected in fresh marrow was pseudodiploid (46, XY, -15, t [9;22] [q34; q11], +mar), whereas colony blasts were hyperdiploid with additional SCA $(52, \mathrm{XY},+\mathrm{X}$, $+20, t[2 ; 14]$ [p11; q32], +4mar). Despite the observed differences with fresh marrow blasts, colony blasts in all three cases had SCA that confirmed their leukemic origin.

Among the 33 cases with successful cultures, we could identify two major immunological groups based on expression of CALLA. In the first group of 22 CALLA $^{+}$patients $(67 \%)$, cultured $B$ cell precursor ALL cells from primary day 7 blast colonies were CALLA ${ }^{+}$. In the second group of 11 CALLA $^{+}$ patients (33\%) (UPN 7, 14, 16, 18, 24, 30, 35, 38, 46, 47, and 50 ), colony blasts did not express detectable amounts of CALLA. Colony blasts in both groups were always positive for at least two distinct $B$ lineage markers. In replating experiments, the immunophenotype of cultured blasts from secondary colonies was identical to that of B lineage blasts from primary day 7 colonies. Most importantly, CALLA ${ }^{-}$colony blasts yielded CALLA ${ }^{-}$secondary colonies (UPN 7 and 24), and $\mathrm{CALLA}^{+}$colony blasts yielded CALLA ${ }^{+}$secondary colonies (UPN 3, 13, 22, 23, 32, 34, and 39). Notably, cultured blasts from each case had slightly different marker profiles. These findings suggest the existence of at least two immunologically distinct $\left(\mathrm{CALLA}^{-}\right.$and $\mathrm{CALLA}^{+}$) leukemic progenitor cell populations in $\mathrm{CALLA}^{+} \mathrm{B}$ cell precursor ALL. This hypothesis is further supported by our initial cytogenetic studies on leukemic B cell precursor colony blasts. Primary colony blasts from UPN 38 were not only $\mathrm{CALLA}^{-}$, but they also had a completely different karyotype from the malignant clone detected in the fresh marrow sample that contained $88 \%$ $\mathrm{CALLA}^{+}$blasts.

Associations between in vitro colony formation and other laboratory and clinical parameters. As shown in Table IV, a very pronounced association was established between PE and the karyotypic findings. The mean PE values of fresh marrow blasts from patients with a normal diploid $(n=2)$ and hyperdiploid $(n=11)$ clone were 0.09 and $0.35 \%$, respectively. Among these 23 cases, only UPN 5, 42, and 45 had PE values higher than the median PE. Significantly, all three patients were hyperdiploid with additional SCA. Bone marrow blasts from 5 of 11 patients (45\%) with a hyperdiploid karyotype and from 5 of 12 patients (42\%) with a normal diploid karyotype failed to proliferate and form colonies. By comparison, marrow blasts from all patients with a pseudodiploid or hypodiploid karyotype and additional SCA formed blast colonies with a mean PE value of $1.21 \%$. This value is significantly different from the PE values of marrow blasts from normal diploid and hyperdiploid cases $(P<0.001)$. The $P E$ values for 9 of 11 patients $(82 \%)$ in this group were higher than the median PE (i.e., 0.408\%). When we compared the mean PE values for all patients with and without, SCA we again found a very significant difference $(1.04 \%$ vs. $0.10 \%, P<0.001)$. Particularly, note that only patients with SCA had a PE higher than the median value of $0.408 \%$. Notably, the in vitro growth patterns of marrow blasts from patients with similar cytogenetic abnormalities were consistent; two patients with aberrations involving 7 p13 (UPN 3 and 39), two with cytogenetic abnormalities involving 11 q23-24 (UPN 3 and 17), four with SCA involving $12 \mathrm{p} 11-13$ (UPN 4, 22, 39, and 43), and two with a Philadelphia chromosome (UPN 42 and 47) all had high PE values. Also, a significant association was established between percentage of cells in $\mathrm{S}$ phase $(\% \mathrm{~S})$ of marrow blasts and their PE values $(P<0.05)$. The mean $P E$ of fresh $B$ cell 
Table IV. Significant Statistical Correlations*

\begin{tabular}{llll}
\hline & \multicolumn{2}{l}{$\%$ PE } & \\
\cline { 2 - 4 } Patient subgroups & $n$ & Mean $( \pm$ SE $)$ & $p$ \\
\hline $\begin{array}{l}\text { Normal diploid karyotype } \\
\text { Hyperdiploid karyotype }\end{array}$ & 12 & $0.09( \pm 0.03)$ & \\
$\begin{array}{l}\text { Pseudodiploid karyotype or } \\
\quad \text { hypodiploid karyotype }\end{array}$ & 11 & $0.35( \pm 0.13)$ & $<0.001$ \\
$\quad$ with SCA & 11 & $1.21( \pm 0.26)$ & \\
No SCA & 16 & $0.10( \pm 0.03)$ & $<0.001$ \\
SCA & 16 & $1.04( \pm 0.20)$ & \\
\% S $<4.9$ & 16 & $0.19( \pm 0.08)$ & $<0.050$ \\
\% S $\geq 4.9$ & 15 & $0.74( \pm 0.21)$ & \\
New & 40 & $0.37( \pm 0.01)$ & 0.059 \\
Relapse & 10 & $0.79( \pm 0.25)$ & \\
\hline
\end{tabular}

* The mean $( \pm \mathrm{SE})$ PE of leukemic B cell precursor blasts were compared (in the log scale) using two-sample, two-sided student's $t$ tests and analysis of variance.

precursor ALL marrow blasts was significantly higher in patients with an $\mathrm{S}$ phase fraction that was greater than the median $\% \mathrm{~S}$, than in patients with smaller $\mathrm{S}$ phase fractions $(0.74 \%$ vs. $0.19 \%, P<0.05)$. Furthermore, this correlation between $\% \mathrm{~S}$ and $\mathrm{PE}$ was also significant on a continuous scale $(r=0.36$, $P<0.05)$. Notably, a significant correlation was also found between expression of the B lineage marker B43 and PE ( $r$ $=0.38, P<0.05$ ). A nonsignificant trend was present toward higher PE values in relapsed vs newly diagnosed patients $(P$ $=0.059$ ). We examined the combined effects of karyotype, $\% \mathrm{~S}, \mathrm{CD} 19$, and relapse status on PE by means of a multiple regression analysis. Karyotype remained a highly significant predictor of PE when the other variables were taken into account $(P<0.001)$. All multiple regression models, which included karyotype as an independent variable, provided a significant prediction of PE. Other continuous or categorical variables, including age, sex, WBC at diagnosis, and FAB morphology did not improve prediction of $P E$ when added to any of the multiple regression models that included karyotype. PE was not correlated with sex, age, FAB morphology, WBC at the time of diagnosis, DI, nor expression of CD9, CD10, or CD24 on fresh marrow blasts.

\section{Discussion}

In the present study, we used a leukemic progenitor cell assay system (6) to analyze the in vitro proliferative activity of fresh marrow blasts from $50 \mathrm{~B}$ cell precursor ALL patients in relationship to other commonly measured disease- and host-related parameters. Our findings demonstrate a pronounced association between the proliferative activity of leukemic B cell precursors and their karyotypic features.

Blast colony formation was observed for 33 patients and the PE showed a marked interpatient variation, indicating a pronounced biological heterogeneity at the level of leukemic progenitor cells. Notably, the mean PE of leukemic B cell precursor blasts from patients with a pseudodiploid or neardiploid karyotype with SCA was significantly higher than the mean PE of normal diploid or hyperdiploid cases. Overall, the mean PE of leukemic B cell precursors from patients with SCA was 10 -fold higher than that for patients without SCA. The underlying reason for these marked differences in PE among ALL patients with different karyotypic findings is as yet unknown. Researchers have suggested that translocations might alter the expression of a cellular transforming gene by bringing it under the control of a new promoter-enhancer $(18,19)$. To date, cellular oncogenes have been mapped to human chromosomes 1-9, 11, 12, 14, 15, 17-22, and X (18). A remarkable concordance has occurred between the chromosomal location of these protooncogenes and the breakpoints involved in chromosome translocations-deletions, especially in leukemias and lymphomas (18). Chromosomal rearrangements and fusion near or at the sites of cellular oncogenes can result in activation of the relevant transforming genes and/or production of novel fused transcripts of two genes-oncogenes (20-24). There is accumulating evidence that the products of a number of protooncogenes show structural and functional near-identity to growth factors or growth factor receptors (25-28). Hence, activation of these cellular oncogenes by chromosomal rearrangements may result in an autocrine stimulation of cell growth and provide leukemic blasts with a proliferative advantage $(19,20,26)$. Alternatively, some oncogenes may confer growth autonomy via indirect mechanisms, such as the postreceptor signal transduction pathways that generate a mitogenic response in target cells. Significantly, the in vitro growth patterns of marrow blasts from B cell precursor ALL patients with similar cytogenetic abnormalities were consistent. All patients who had SCA involving 7p13, 11q23-24, or 12p11-13, and patients with a Philadelphia chromosome had high PE values: C-erb $B$ has been mapped to band p13 on the short arm of chromosome 7 (18). The break point on chromosome 7 in both UPN 3 and 39 was at this locus, and both cases yielded a high PE. The oncogene Hu-ets-1 has been mapped to band q23-24 on the long arm of chromosome 11 (18). Sacchi et al. recently demonstrated that this gene can translocate from its normal position as a consequence of chromosomal rearrangements involving the 11q23-24 breakpoint (29). The Huets- 1 product has been postulated to be a growth-regulatory factor (29). We observed intriguingly high numbers of blast colonies in marrow samples from both patients with cytogenetic abnormalities involving 11q23-24 (UPN 3 and 17). Four patients (UPN 4, 22, 39, and 43) had SCA involving the same region on the short arm of chromosome 12 (bands p11-13), and all four had high PE values. It is noteworthy that c-Kras 2 oncogene has been mapped to the same region (18). Similarly, both patients with a Philadelphia chromosome (UPN 42 and 47) had very high PE values.

Besides the karyotypic findings, the $\mathrm{S}$ phase cell percentage also had a statistically significant predictive value for PE. This indicates that cell cycle kinetic properties greatly affect the in vitro growth capacity of leukemic B cell precursors. Fresh marrow blasts from relapsed patients had a twofold higher PE than blasts from newly diagnosed patients. This finding corroborates the fact that the vast majority of leukemic cell lines reported in literature have been established using marrow samples from ALL patients in relapse (30).

The immunological surface marker profiles of all $50 \mathrm{ALL}$ patients were consistent with B lineage affiliation. Despite the similarities in expression of B lineage-associated surface antigens, a marked variation in the in vitro growth characteristics existed among these B cell precursor ALL patients. Remarkably, a significant correlation was found between CD19 ex- 
pression on fresh leukemic B cell precursors and their PE. An intriguing possibility is that the function of this determinant may be related to growth control in B cell precursor ALL. PE was not correlated with sex, age, FAB morphology, WBC at diagnosis, DI, nor expression of CD9, CD10, or CD24 on leukemic B cell precursor blasts.

From the surface marker analyses of colony blasts in the 33 patients with successful cultures, a marked interpatient variation became apparent in the expression of B lineage surface determinants, not only on the bulk of marrow blasts, but also on the clonogenic subpopulations. Colony cells from each successfully cultured B cell precursor ALL case had slightly different marker profiles. In 33\% of cases, cultured blasts did not express detectable amounts of CALLA, although the initial blast populations were strongly positive for this determinant. Replating experiments were performed to test the self-renewal ability of day 7 colony blasts and the stability of their immunophenotype. Secondary colonies were obtained in patients with both $\mathrm{CALLA}^{+}$and CALLA ${ }^{-}$primary colonies. The secondary PE values of $\mathrm{CALLA}^{+}$and $\mathrm{CALLA}^{-}$colony blasts were comparable. Since the bulk of initial marrow blasts in all patients were $\mathrm{CALLA}^{+}$, and the described culture conditions did not appear to provide a selective growth advantage for $\mathrm{CALLA}^{-}$blasts, the presented data indicate the existence of $\mathrm{CALLA}^{-}$leukemic progenitor cells in a number of patients with $\mathrm{CALLA}^{+} \mathrm{B}$ cell precursor ALL. Our hypothesis is supported by the clinical observation that the dominant leukemic immunophenotype may change in an individual B cell precursor ALL patient $(31,32)$. In one series of 143 patients with $B$ lineage ALL, 19 showed an altered phenotype at relapse, and the most common change was either the loss or acquisition of CALLA (31). Our findings also agree with Toew et al., who sorted and successfully cultured CALLA ${ }^{+}$as well as CALLA ${ }^{-}$ blast fractions in two patients with B cell precursor ALL (5).

In summary, we have used a colony assay system to detail the in vitro growth characteristics of fresh marrow blasts and the immunophenotypic features of cultured marrow blasts from 50 B cell precursor ALL patients. Our study exemplifies how this leukemic progenitory cell assay can be used to illuminate the heterogeneity among B cell precursor ALL patients with different clinical-laboratory findings. To our knowledge, this report represents the first detailed comparative analysis of the proliferative activity of clonogenic fresh marrow blasts from B cell precursor ALL patients. Our data provide unique and direct evidence for $(a)$ a marked heterogeneity at the level of leukemic progenitor cells in B cell precursor ALL and $(b)$ a significant correlation between the in vitro proliferative activity of leukemic B cell precursors and certain structural chromosomal abnormalities. Future studies will be necessary to evaluate the prognostic value of in vitro colony formation as a new biological parameter.

\section{Acknowledgments}

The authors thank Dr. F. Bollum for providing anti-TdT Ab; Dr. J. D. Griffin for, MY7 and MY8 mAb; Dr. P. A. Edwards for, R10 mAb; Dr. T. W. LeBien for, BA-1, -2, and -3 mAb; and Dr. A. Goldman for her statistical analyses. Evelyn Usher and Timothy B. Dickson contributed excellent technical assistance. We are grateful to Jo Ann Mattson for her excellent secretarial services and to Mary Jane Hildreth for her exceptional editorial assistance.

This work was supported in part by National Cancer Institute grants 5R29 CA-42111-01, CA-31618, CA-36725, CA-25097, and
CA-42633; by American Cancer Society grant IM-380; and a special grant (SMF-514-86) from the Minnesota Medical Foundation. Dr. Uckun is a New Investigator of the National Institutes of Health and Special Fellow of the Leukemia Society of America. Dr. Vallera is a Scholar of the Leukemia Society of America.

\section{References}

1. Smith, S. D., E. M. Uyeki, and J. T. Lowman. 1978. Colony formation in vitro by leukemic cells in acute lymphoblastic leukemia (ALL). Blood. 52:712-718.

2. Izaguirre, C. A., J. Curtis, H. Messner, and E. A. McCulloch. 1981. A colony assay for blast progenitors in non-B non-T (common) acute lymphoblastic leukemia. Blood. 57:823-829.

3. Paolucci, P., N. T. Rapson, L. Layward, and A. R. Hayward. 1981. Growth of pre-B cells in cultures of bone marrow from children with acute lymphoblastic leukemia and other diseases. Clin. Exp. Immunol. 43:143-148.

4. Stong, R. C., and J. H. Kersey. 1985. In vitro culture of leukemic cells in $t(4 ; 11)$ acute leukemia. Blood. 66:439-443.

5. Touw, I., R. Delwel, R. Bolhuis, G. van Zanen, and B. Lowenberg. 1985. Common and pre-B acute leukemia cells express IL-2 receptors and in vitro colony formation is stimulated in the presence of interleukin 2. Blood. 66:556-561.

6. Uckun, F. M., K. J., Gajl-Peczalska, J. H. Kersey, L. L. Houston, and D. A. Vallera. 1986. Use of a novel colony assay to evaluate the cytotoxicity of an immunotoxin containing pokeweed antiviral protein against blast progenitor cells freshly obtained from patients with common B-lineage acute lymphoblastic leukemia. J. Exp. Med. 163:347368.

7. Uckun, F. M., K. J. Gajl-Peczalska, D. E. Myers, N. C. Ramsay, J. H. Kersey, M. Colvin, and D. A. Vallera. 1987. Marrow purging in autologous bone marrow transplantation for T-lineage acute lymphoblastic leukemia: efficacy of ex vivo treatment with immunotoxins and 4-hydroperoxycyclophosphamide against fresh leukemic marrow progenitor cells. Blood. 69:361-366.

8. McCulloch, E. A. 1983. Stem cells in normal and leukemic hemopoiesis. Blood. 62:1-13.

9. Miller, D., S. Leikin, V. Albo, H. Sather, and D. Hammond. 1981. Prognostic importance of morphology (FAB classification) in childhood acute lymphoblastic leukemia. Br. J. Hematol. 48:199-206.

10. ISCN (1981): an international system for human cytogenetic nomenclature-high resolution banding. 1981. Cytogenet. Cell Genet. 31:1-50.

11. Arthur, D. C., C. D. Bloomfield, L. L. Lindquist, and M. E. Nesbit. 1982. Translocation 4;11 in acute lymphoblastic leukemia: clinical characteristics and prognostic significance. Blood. 59:96-99.

12. Dewald, G. W., R. A. Kyle, G. A. Hicks, and P. R. Greipp. 1985. The clinical significance of cytogenetic studies in 100 patients with multiple myeloma, plasma cell leukemia or amyloidosis. Blood. 66:380-390.

13. Heerema, N. A., C. G. Palmer, and R. L. Baehner. 1985. Karyotypic and clinical findings in a consecutive series of children with acute lymphocytic leukemia. Cancer Gene. Cytogenet. 17:165-179.

14. Haag, D. 1980. Flow microfluorometric deoxyribonucleic acid (DNA) analysis supplementing routine histopathologic diagnosis of biopsy specimens. Lab. Invest. 42:85-90.

15. Haag, D., K. Goerttler, and C. Tschahargane. 1984. The proliferative index (PI) of human breast cancer as obtained by flow cytometry. Pathol. Res. Pract. 178:315-322.

16. Uckun, F. M., S. Ramakrishnan, and L. L. Houston. 1985. Increased efficiency in selective elimination of leukemia cells by a combination of a stable derivative of cyclophosphamide and a human B-cell specific immunotoxin containing pokeweed antiviral protein. Cancer Res. 45:69-75.

17. Uckun, F. M., S. Ramakrishnan, D. Haag, and L. L. Houston. 1985. Ex vivo elimination of lymphoblastic leukemia cells from human marrow by mafosfamid. Leuk. Res. 9:83-95. 
18. Berger, R., C. D. Bloomfield, and G. R. Sutherland. 1985. Chromosomal Rearrangements. Human Gene Mapping, $8^{\text {th }}$ International Workshop on Human Gene Mapping. Cytogenet. Cell Genet. 40:515-535.

19. Nowell, P. C., B. S. Emanuell, J. B. Finan, J. Erikson, and C. M Croce. 1985. Chromosome alterations in oncogenesis. In Modern Trends in Human Leukemia. VI. New Results in Clinical and Biological Research including Pediatric Oncology. R. Neth, R. Gallo, M. F. Greaves, G. Janka, editors. Springer-Verlag, Berlin, Heidelberg, New York. 253-260.

20. Adams, J. M. 1985. Oncogene activation by fusion of chromosomes in leukemia. Nature (Lond.). 315:542-543.

21. Erikson, J., A.ar-Rushdi, H. Drwinga, P. Nowell, and C. Croce. 1983. Transcriptional activation of the translocated c-myc oncogene in Burkitt's lymphoma. Proc. Natl. Acad. Sci. USA 80:820-824.

22. Croce, C., W. Thierfelder, J. Erikson, K. Nishukura, J. Finan, G. Lenoir, T. Rabbitts, and P. Nowell. 1983. Transcriptional activation of an unrearranged and untranslocated c-myc oncogene by translocation of a C-lambda locus in Burkitt's lymphoma cells. Proc. Natl. Acad. Sci. USA. 80:6922-6926.

23. Erikson, J., K. Nishikura, A.ar-Rushdi, J. Finan, B. Emanuel, G. Lenoir, P. C. Nowell, and C. M. Croce. 1983. Translocation of an immunoglobulin kappa locus to a region $3^{\prime}$ of an unrearranged c-myc oncogene enhances c-myc transcription. Proc. Natl. Acad. Sci. USA. 80:7581-7585.

24. Shtivelman, E., B. Lifshitz, R. P. Gale, and E. Canaani. 1985. Fused transcript of abl and bcr genes in chronic myelogenous leukemia. Nature (Lond.). 315:550-554.
25. Bishop, J. M. 1985. Viral Oncogenes. Cell. 42:23-38.

26. Sporn, M. B., and A. B. Roberts. 1985. Autocrine growth factors and cancer. Nature (Lond.). 313:745-749.

27. Hunter, T. 1984. The epidermal growth factor receptor gene and its product. Nature (Lond.). 311:415-421.

28. Sherr, C. J., C. W. Rettenmier, R. Sacca, M. F. Roussel, A. T. Look, and E. R. Stanley. 1985. The c-fms proto-oncogene product is related to the receptor for the mononuclear phagocyte growth factor, CSF-1. Cell. 41:665-669.

29. Sacchi, N., D. K. Watson, A. H. M. G. VanKessel, A. Hagemeijer, J. H. Kersey, H. D. Drabkin, D. Patterson, and T. S. Papas. 1986. Hu-ets-1 and Hu-ets-2 genes are transposed in acute leukemias with 4;11 and 8;21 translocations. Science (Wash. DC). 231:379-382.

30. Minowada, J., T. Tsubota, S. Nakazawa, B. I. S. Srivastava, C. C. Huang, M. Oshimura, S. Sonta, T. Han, L. F. Sinks, and A. A. Sandberg. 1977. Establishment and characterization of leukemic T-cell lines, B-cell lines, and null-cell line: a progress report on surface antigen study of fresh lymphatic leukemias in man. Hematol. Bloodtransfus. 20:241-250.

31. Greaves, M. F. 1981. Analysis of the clinical and biological significance of lymphoid phenotypes in acute leukemia. Cancer Res. 41:4752-4766.

32. Ramsay, N., T. W. LeBien, M. Nesbit, P. McGlave, D. Weisdorf, P. Kenyon, D. Hurd, A. Goldman, T. Kim, and J. H. Kersey. 1985. Autologous bone marrow transplantation for patients with acute lymphoblastic leukemia in second or subsequent remission: results of bone marrow treated with monoclonal antibodies BA-1, BA-2, BA-3 pls complement. Blood. 66:508-513. 